\title{
Predation of Scinax ruber (Anura: Hylidae) tadpoles by a fishing spider of the genus Thaumisia (Araneae: Pisauridae) in south-east Peru
}

\author{
CRISTINA ARRIVILLAGA*, JOSEPH OAKLEY \& SAMUEL EBINER \\ Crees Foundation, Urbanización Mariscal Gamarra B-5, Zona 1, Cusco, Peru \\ ${ }^{*}$ Corresponding author e-mail: cristinaarrivillaga@gmail.com
}

\begin{abstract}
$T_{\text {h }}^{\text {h }}$ he red-snouted tree frog, Scinax ruber, is a medium sized hylid frog that is widely distributed throughout the Amazon basin where it mainly inhabits cleared areas of rainforest, as well as agricultural lands (Solis et al., 2010). This species breeds year-round, with the females depositing eggs on the vegetation overhanging temporary ponds where the tadpoles later develop (Solís et al., 2010). Temporary water sources are known to harbour fewer predators than permanent water sources (Skelly \& Werner, 1990; Skelly, 1997; Wild, 1996) but semi-aquatic and terrestrial predators may be unaffected by the lifespan of the water source. This is the case with nursey web or semi-aquatic spiders (Pisauridae), as there are several reports of such spiders predating anurans (Bernarde et al., 1999; Mendes Luiz et al., 2013; Bovo et al., 2014; von May et al., 2019).

At $21.39 \mathrm{~h}$ on 5 October 2018, an S. ruber tadpole was observed held between the chelicerae and pedipalps of a Thaumasia sp. (Pisauridae) spider on the lip of a water-filled barrel (Fig. 1). The spider appeared to be chewing the S. ruber tadpole, as the authors saw it moving its mouthparts while holding it. The sighting occurred during a night time survey in the biogarden area of the Manu Learning Centre $\left(12.78917^{\circ} \mathrm{S}\right.$, $71.39111^{\circ} \mathrm{W}, \mathrm{WGS} 84,460 \mathrm{~m}$ elev.), a research station situated in the buffer zone of the Manu National Park in south-east Peru. The specimens were observed and photographed but not collected. To give a tentative identification of the predated tadpole, others from the same location were identified using the guide of Schulze et al. (2015). Predation events of Scinax adults, tadpoles (Machado \& Mendes, 2014; Pinto-Silva \& Bruno, 2018) and other hylids (Santos-Silva et al., 2013; Mendes Luiz et al., 2013; von May et al., 2019) by Thaumasia have been reported previously but to the best of our knowledge predation of $S$. ruber tadpoles by Thaumasia has not been documented. This observation provides an interesting addition to prey-predator interactions between anurans and spiders.
\end{abstract}

\section{ACKNOWLEDGMENTS}

We would like to thank The Crees Foundation for providing the opportunity to conduct herpetological surveys at the Manu Learning Centre. Special thanks to Tom Brown for his overall help and to Brittany Damron for her aid in the spider identification, as well as Andrew Lee for his help reviewing this note.

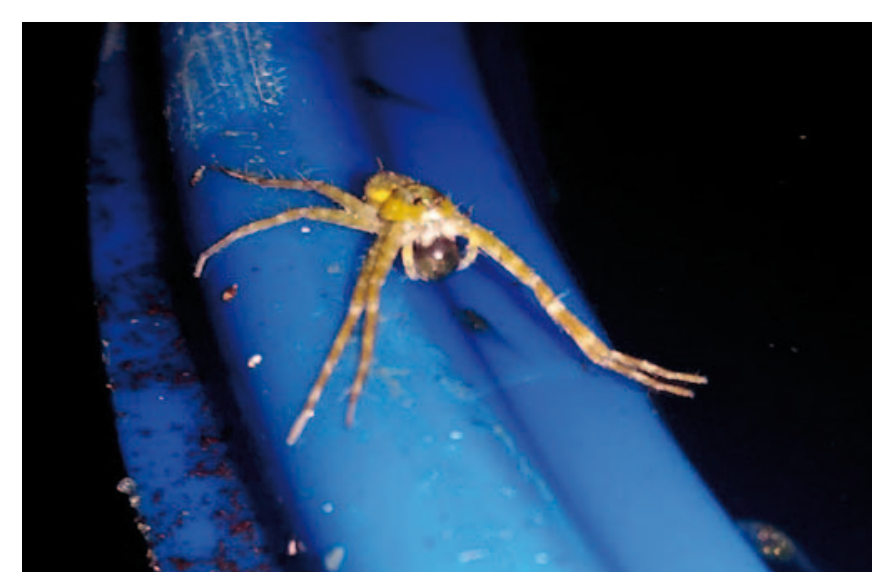

Figure 1. Thaumasia (Pisauridae) holding a S. ruber tadpole in the Manu Learning Centre, Peru

\section{REFERENCES}

Bernarde, P. S., Souza, M. B. \& Kokubum, M. C. N. (1999). Predation on Hyla minuta Peters, 1872 (Anura, Hylidae) by Ancylometes spp. (Araneae, Pisauridae). Biociências 7: 199-203.

Bovo, R. P., Oliveira, E. G. \& Bandeira, L.N. (2014). Predation on two Dendropsophus species (Anura: Hylidae) by a pisaurid spider in the Atlantic forest, southeastern Brazil. Herpetology Notes: 329-331.

Mendes Luiz, A., Pires, T. A., Dimitrov, V. \& Sawaya R. J. (2013). Predation on tadpole of Itapotihyla langsdorffii (Anura, Hylidae) by the semi-aquatic spider Thaumasia sp. (Araneae, Pisauridae) in the Atlantic Forest, southeastern Brazil. Herpetology Notes: 451-452.

Machado, M. \& Mendes Lipinski, V. (2014). Predation event on tadpoles of Scinax aromothyella (Anura: Hylidae) by the fishing spider Thaumasia velox (Araneae: Pisauridae) in a rainforest of southern Brazil. Herpetology Notes: $517-$ 518.

Pinto-Silva, S. \& Bruno Neuhaus, E. (2018). Scinax alter. Predation. Herpetological Review 49: 100-101.

Santos-Silva, C. R., Santos, E. D. S., Gomes, L. \& Ferrari, S. F. (2013). Predation of a Phyllomedusa nordestina tadpole (Anura, Hylidae) by a fishing spider, Thaumasia sp. (Areneae, Pisauridae), in a temporary pond in the Raso 
da Catarina, Bahia, Brazil. Herpetology Notes 6: 193-194.

Schulze, A., Jansen, M. \& Kohler, G. (2015). Tadpole diversity of Bolivia's lowland anuran communities: Molecular identification, morphological characterisation, and ecological assignment. Zootaxa. Magnolia Press. 111.

Skelly, D. K. (1997). Pond permanence and predation are powerful forces shaping the structure of tadpole communities. Tadpole communities. American Scientist 85: 36-45.

Skelly, D. K, Werner, E. E. (1990). Behavioral and life-historical responses of larval American toads to an odonate predator. Ecology 71: 2312 - 2312.

Solís, F., Ibáñez, R., Jaramillo, C., Fuenmayor, Q., AzevedoRamos, C., La Marca, E., Coloma, L.A., Ron, S., Hardy, J., Hedges, B., Ibéné, B., Breuil, M. \& Powell, M. (2010). Scinax ruber. The IUCN Red List of Threatened Species 2010: e.T55994A11395509.http://dx.doi.org/10.2305/IUCN. UK.2010-2.RLTS.T55994A11395509.en. Downloaded on 22 March 2019. von May, R., Biggi, E., Cárdenas, H., Diaz M. I., Alarcón, C., Herrera, V., Santa-Cruz, R., Tomasinelli, F., Westeen, E.P., Sánchez-Paredes, C. M., Larson, J.G., Title, P. O., Grundler, M.R., Grundler, M. C., Rabosky, A. R. D. \& Rabosky, D. L. (2019). Ecological interactions between arthropods and small vertebrates in a lowland Amazon rainforest. Amphibian \& Reptile Conservation 13(1) [General Section]: 65-77 (e169).

Wild, E. (1996). Natural history and resource use of four Amazonian resource assemblages. Occasional Papers of the Natural History Museum of the University of Kansas 176: 1-59.

Accepted: 24 April 2019 